\title{
EVIDENCE FOR A LOST MILLENNIUM IN BIBLICAL CHRONOLOGY1
}

\author{
G. E. AARDSMA ${ }^{2}$
}

Institute for Creation Research, 10946 Woodside Ave. N., Santee, California 92071 USA

\begin{abstract}
Biblical and secular data seem to tell entirely different stories about Near Eastern history prior to the first millennium BC. Most modern critical scholars in Bible-related fields regard this as proof of the nonhistoricity of the premonarchical biblical narrative. However, the incongruity between biblical and secular data seems also to be explainable by the postulate that exactly $1000 \mathrm{yr}$ were accidentally dropped from traditional biblical chronology just prior to the first millennium BC. I evaluate this postulate relative to extra-biblical data for the exodus, Joseph's famine and Lot's observation that the Jordan valley was "well watered" in his day. The repeated success of this postulate in integrating much archaeological, historical and geophysical data with the biblical narrative offers support for the historicity of the premonarchical biblical narrative. Biblical chronology, when corrected by the restoration of the lost $1000 \mathrm{yr}$, promises to reduce present uncertainties in secular historical chronologies in the 3rd and 4th millennia BC by at least an order of magnitude.
\end{abstract}

\section{INTRODUCTION}

The prevailing view among modern critical scholars in Bible-related fields is that the biblical narrative does not represent reliable history prior to roughly the first millennium $\mathrm{BC}$. The accomplished Egyptologist Donald B. Redford has candidly and succinctly expressed this view in concluding that "the Biblical writers are wholly and blissfully unaware of the colossal discrepancy to which their 'history' and 'chronology' have given rise" (Redford 1992: 259).

Proponents of this view feel it is strongly supported by a great wealth of modern data from archaeological and historical sources. To take a single archaeological example, they point out that although the biblical narrative implies that Jericho, Ai and numerous other cities in Palestine were destroyed ca. $1410 \mathrm{BC}$ by an Israelite leader named Joshua (Josh. 6-12), archaeological excavations tell an entirely different story. Excavations at the ancient site of Jericho by Kathleen Kenyon from 1952 to 1959 led her to conclude that no city existed there anywhere near 1410 BC (Kenyon 1957: 262), and excavations at Ai by Joseph Callaway resulted in a similar conclusion (Callaway 1985, 1993).

It is possible to multiply such archaeological examples many times over, but let us turn to a historical one. The biblical narrative as it presently reads implies that the period of the Judges of Israel occupied most of the second half of the second millennium BC. Redford (1992: 259) has pointed out that this is "almost exactly coeval with the Egyptian empire in Asia! Yet our Egyptian sources mention neither the patriarchs, Israel in Egypt, Joshua, nor his successors, while the Bible says absolutely nothing about the Egyptian empire in the land".

For the past several decades, the abundance of such incongruities has made the postulate of the biblical narrative's nonhistoricity seem the only rational alternative. Recently, however, I began to suspect these incongruities might have an entirely different explanation. Specifically, a large enough chronological offset between the biblical narrative and secular history prior to the first millennium $\mathrm{BC}$ could also produce an apparent incompatibility between them.

This possibility is strengthened by the observation that incongruities of this sort appear only prior to the first millennium. The biblical narrative of events that fall within the first millennium $B C$ has repeatedly been corroborated by archaeology and secular history. Today, nobody seriously ques\footnotetext{
${ }^{1}$ The author and editors hope that this paper will generate constructive response to its radical revision of biblical chronology
based upon the application of ${ }^{14} \mathrm{C}$ dates.

${ }^{2}$ Present address: 412 N. Mulberry, Loda, Illinois 60948-9651 USA
} 
tions, for example, that a nation called Israel existed in Palestine in the first millennium, that it was ruled by a monarchy, that Jerusalem was captured and destroyed by Nebuchadnezzar, and that the consequent, biblically recorded exile really took place. In fact, it is possible to date many first millennium BC biblical events very precisely. For example, scholars generally agree that the final destruction of Jerusalem by Nebuchadnezzar occurred in 586 BC (Shiloh 1993), and the fall of Samaria occurred in 722 BC (Avigad 1993).

This sort of transition from disharmony to harmony at a single point in time is precisely what one would expect to find if for some reason there existed a significant chronological offset at the transition point. There is, in fact, a simple way in which such a chronological offset could have come about. Biblical chronology prior to the first millennium $\mathrm{BC}$ is entirely dependent upon one number, found in the Bible only in 1 Kings 6:1. ${ }^{3}$ The fact that 1 Kings was hand-copied by scribes following its composition $c a .550 \mathrm{BC}$ creates the possibility that this number was copied incorrectly at some point in the past. Just as today misplacement of a tiny decimal point can substantially alter the magnitude of a number, so in the past a tiny slip on the part of an ancient scribe could result in a very large quantitative change in a number being copied. Although comparison of extant ancient manuscripts shows that inaccurate transcription of biblical numbers in antiquity was not a common phenomenon, it also reveals unequivocally that such transcription errors did occur from time to time (cf. Archer 1974: 57). A single transcription error in 1 Kings 6:1 could conceivably have given rise to a large error in the number found there, introducing a large inaccuracy into biblical chronological computations for times prior to the first millennium BC.

I have now thoroughly investigated this possibility. I have found that there is much cause to believe that this is, in fact, what took place (Aardsma 1993). It appears that the text of 1 Kings 6:1 that presently reads "four hundred and eightieth year" was originally "one thousand four hundred and eightieth year", and that the "one thousand" was accidentally dropped from the text in antiquity. (In Hebrew, "one thousand" is a single three-letter word, easily dropped from the text at this point by accident.) This ancient accident has caused traditional biblical chronological computations to be in error by exactly $1000 \mathrm{yr}$ for all biblical events much prior to the first millennium BC.

Any hypothesis that entails the insertion of a full millennium into an established chronology will necessarily invoke radical consequences. This simple hypothesis involving 1 Kings 6:1 moves the entire Old Testament narrative, from Genesis through Judges, to a place on the time line $1000 \mathrm{yr}$ earlier than has traditionally been supposed. It implies that there is a previously unrecognized large gap in the biblical narrative between the end of the book of Judges and the beginning of the book of 1 Samuel. It suggests that the book of Judges closes at the end of the Intermediate Bronze Age (ca. $2000 \mathrm{BC}$ ), that 1 Samuel does not open until the Iron Age I, and that the Bible offers no history of the Middle or Late Bronze Ages in Palestine.

However, the unavoidably radical nature of this hypothesis also renders it easily falsifiable. Simply stated, obvious absurdities-relative to data from a variety of historical, archaeological and geophysical sources-will immediately result if one attempts to insert $1000 \mathrm{yr}$ into any real historical chronology where it does not belong. Misplaced 1000-yr insertions are easily spotted.

In the present case, such absurdities have not been found. Rather, the addition of $1000 \mathrm{yr}$ to traditional biblical chronology as specified above has immediately harmonized much of the premonar-

\footnotetext{
3"Now it came about in the four hundred and eightieth year after the sons of Israel came out of the land of Egypt, in the fourth year of Solomon's reign over Israel, in the month of Ziv which is the second month, that he began to build the house of the Lord" (New American Standard Bible).
} 
chical biblical narrative with a substantial quantity of extrabiblical data. When the archaeology and history of the Bible lands is viewed panoramically using the proposed biblical dates, the exodus becomes apparent in Egyptian history for the first time (see below); the movement of the Israelites across the northern Sinai and through the central Negev following the exodus can be discerned (Oren and Yekutieli 1990; Cohen 1983, 1984); the biblical account of the conquests of the kingdoms of Sihon and $\mathrm{Og}$ in the Transjordan, and simultaneous avoidance of Moab by the Israelites under the leadership of Moses, finds immediate archaeological support (Kochavi 1993; Kautz 1986: 390); the conquest of Palestine is clearly seen in the termination of the Early Bronze Age civilization in Palestine at the end of the Early Bronze Age III-with very nearly every urban center in Palestine showing destruction (including Jericho and $\mathrm{Ai}$ ) or abandonment, while the urban centers in Lebanon and Syria carried on as usual (Ben-Tor 1992: 124); and the archaeologically revealed, tribally organized, pastoral nomadic people who occupy the land in the Intermediate Bronze Age (Dever 1980) seem completely to fulfill biblical expectations of the Israelites during the period of the Judges.

The fact that this simple hypothesis does not generate immediate absurdities relative to available archaeological, historical and geophysical chronological data, plus its evident ability to integrate a very large body of biblical and secular data into a coherent unity, strongly recommend it for serious consideration and evaluation despite its inherently radical nature.

\section{METHODS}

In this paper, I evaluate this hypothesis with respect to three instances of field data, one archaeological, the remaining two from the field of past climates. All depend upon radiocarbon measurements to a considerable extent.

\section{Case 1: The Exodus}

The exodus is pictured biblically as a national calamity of unique proportions for Egypt. Such a calamity would be expected to result in a sudden, precipitous decline in the fortunes of any nation. Traditional biblical chronology dates the exodus to $c a$. $1450 \mathrm{BC}$ on the basis of the previously mentioned $480 \mathrm{yr}$ of 1 Kings 6:1 and the historical date for Solomon's ascension to the throne of $c a .970$ BC. This traditional biblical date places the exodus in the New Kingdom, during a period of tremendous growth and prosperity in Egypt, a period which was anything but calamitous and where it obviously does not belong.

If the biblical narrative of the exodus is historically accurate and its traditional date is too recent by $1000 \mathrm{yr}$, as the missing millennium hypothesis demands, then a precipitous decline in Egypt's prosperity should be seen $c a$. $2450 \mathrm{BC}$.

At first sight, this hypothesis appears to fail. In modern historical chronologies for Egypt, $2450 \mathrm{BC}$ corresponds roughly to the middle of the Old Kingdom, where a precipitous decline in Egypt's prosperity is not evident and seems most unlikely. However, Haas et al. (1987) have shown, in an extensive ${ }^{14} \mathrm{C}$ survey of Old Kingdom monuments, that the modern chronology of the Old Kingdom of Egypt appears to be off by roughly three centuries. The ${ }^{14} \mathrm{C}$ dates of $>70$ samples analyzed were older than the expectations of modern Egyptian chronology by $374 \mathrm{yr}$, on average. Haas et al. (1987) noted that some of this discrepancy might be due to sample provenience factors. In particular, they observed that their averaged charcoal dates were $100 \mathrm{yr}$ older than their averaged straw dates. They suggested that the difference between the average ${ }^{14} \mathrm{C}$ dates and the modern historically derived chronology of the Old Kingdom might be reduced to $270 \mathrm{yr}$ as a result. 
A 270-yr correction to the modern chronology of Egypt, in harmony with the ${ }^{14} \mathrm{C}$ results of Haas $e t$ al. (1987), places the end of the Old Kingdom at ca. $2450 \mathrm{BC}$. It is well established that the Old Kingdom ended in a sudden, catastrophic, unanticipated national downturn. Thus, if the ${ }^{14} \mathrm{C}$ results of Haas $e t$ al. are accepted, it is reasonable to conclude that a precipitous decline in Egypt's prosperity is seen at $c a .2450 \mathrm{BC}$.

\section{Case 2: Joseph's Famine}

Genesis 41-47 records an interesting climatic anomaly during the time of Joseph. This was a period of $14 \mathrm{yr}$, the first 7 of which were unusually favorable for agriculture in Egypt, and the latter 7 of which were unusually unfavorable, apparently throughout the entire Near East, so that widespread famine rapidly developed. The traditional biblical date for this $14-\mathrm{yr}$ phenomenon is $1886 \mathrm{BC}$.

If the biblical narrative of this climatic anomaly is historically accurate, and the traditional date is off by $1000 \mathrm{yr}$, then evidence of this anomaly, including widespread famine in the Near East, should be apparent in extrabiblical data at ca. $2886 \mathrm{BC}$.

The biblical date is much more precise than current secular chronologies of the Near East are able to be for a period this early. The biblical date has a leeway of about a decade in either direction, while the secular chronologies are uncertain by at least \pm 100 yr. However, the Early Bronze Age I to Early Bronze Age II transition in Palestine is normally dated to within ca. $100 \mathrm{yr}$ of $2900 \mathrm{BC}$. Archaeologist Ram Gophna reported that a sudden severe reduction in urban population accompanied this transition throughout Palestine (Shoemaker 1993). Megiddo, for example, declined from ca. 9000 to $c a .900$ people at this time. Prolonged widespread famine would, of course, bring about such a population reduction.

Other possible evidence for this climatic anomaly comes from data on atmospheric ${ }^{14} \mathrm{C}$ provided by the tree-ring record (Stuiver and Braziunas 1989). Interestingly, the corrected biblical date for this climatic anomaly falls on the rising edge of a large ${ }^{14} \mathrm{C}$ peak (Fig. 1). These ${ }^{14} \mathrm{C}$ peaks are understood to result from periods of reduced solar output (Stuiver and Braziunas 1989). A number of researchers have discussed the possibility of a link between solar variability and large-scale climatic anomalies in the past (e.g., Bray 1971; Eddy 1976; Sonett and Suess 1984; Wigley and Kelly 1990; Davis 1992). The temporal coincidence of the biblical record of a 14-yr climatic anomaly and this ${ }^{14} \mathrm{C}$ oscillation is certainly suggestive in this regard. It raises the possibility that a single solar oscillation was responsible for both. This appears to be the oldest historical record showing coincidence between a solar oscillation and a climatic anomaly.

Thus, it does appear that reasonable evidence of a climatic anomaly can be adduced at $c a .2886 \mathrm{BC}$, including the possibility of widespread famine in the Near East.

\section{Case 3: Aridity of the Jordan Valley}

Genesis 13:10 says, "And Lot lifted up his eyes and saw all the valley of the Jordan, that it was well watered everywhere...". The valley of the Jordan is notoriously arid today, and it appears to have been so for a long time in the past. Could it have been "well watered" at the time of Abraham and Lot? Traditional biblical chronology dates Lot's observation to within about a decade of $2080 \mathrm{BC}$. If this biblically recorded observation is historically accurate, and the traditional date is off by $1000 \mathrm{yr}$, then evidence of a moist period in the Jordan valley should be apparent in extrabiblical data at $c a$. $3080 \mathrm{BC}$. 


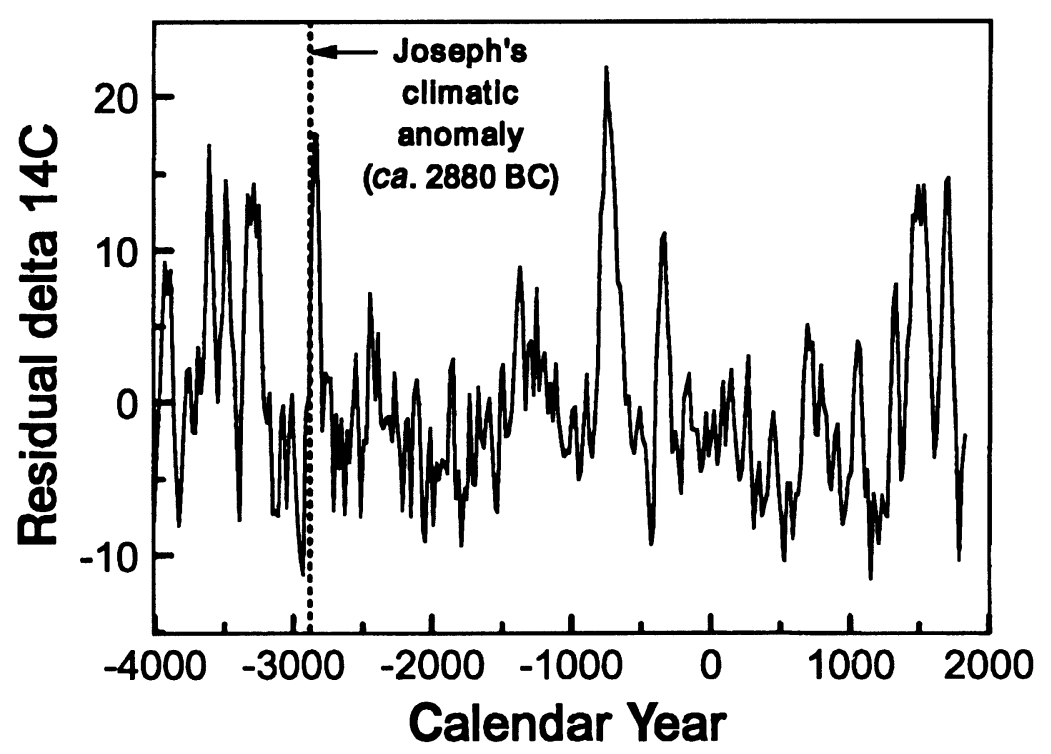

Fig. 1. Temporal coincidence between the biblically recorded climatic anomaly at the posited time of Joseph and a peak in the residual ${ }^{14} \mathrm{C}$ data from tree-rings. (The residual ${ }^{14} \mathrm{C}$ data is from the file RESIDUAL.14C supplied with CALIB 3.0.3 (Stuiver and Reimer 1993).)

Frumkin et al. (1991) published a curve showing the Dead Sea level for the past $7000{ }^{14} \mathrm{C}$ yr. The level of the Dead Sea is a function of the precipitation/evaporation ratio in the Dead Sea catchment area, and Frumkin et al. (1991) have used it as a paleoclimatic indicator of "moist" and "arid" periods in this area. Their curve is based on the passage-width ratio of karstic (solutional) caves that act as conduits to transport runoff through Mount Sedom into the Dead Sea. (Mount Sedom is a salt diapir on the west shore of the southern basin of the Dead Sea.) Their time scale is provided by ${ }^{14} \mathrm{C}$ dates on wood fragments left behind in alluvial clastic sediments within the cave passages.

Figure 2 shows the remarkable temporal coincidence between Lot's biblically recorded observation of a "well watered" valley at the new biblical date and a singular moist episode in the Dead Sea catchment basin according to Frumkin et al. (1991).

\section{Discussion}

The currently prevailing postulate that the biblical narrative is nonhistorical prior to the first millennium $\mathrm{BC}$ removes the apparent discrepancy between biblical and secular data in this time period, but it does so by dismissing or severely devaluing the biblical historical data. Explanations requiring for their success that large portions of data be dismissed as somehow invalid are generally regarded as inferior to explanations that are able to integrate the bulk of the data in a straightforward manner. The postulate that the only error in the biblical data is that $1000 \mathrm{yr}$ has accidentally been dropped from the text of 1 Kings $6: 1$, although radical in its consequences relative to current views, is inherently simple and successfully achieves such a synthesis.

In the introduction, I pointed out that it is impossible to insert a full $1000 \mathrm{yr}$ in any chronology where it does not belong without generating immediate absurdities. It is correspondingly true that you cannot remove a millennium from a chronology where it really does belong and fail to generate numer- 


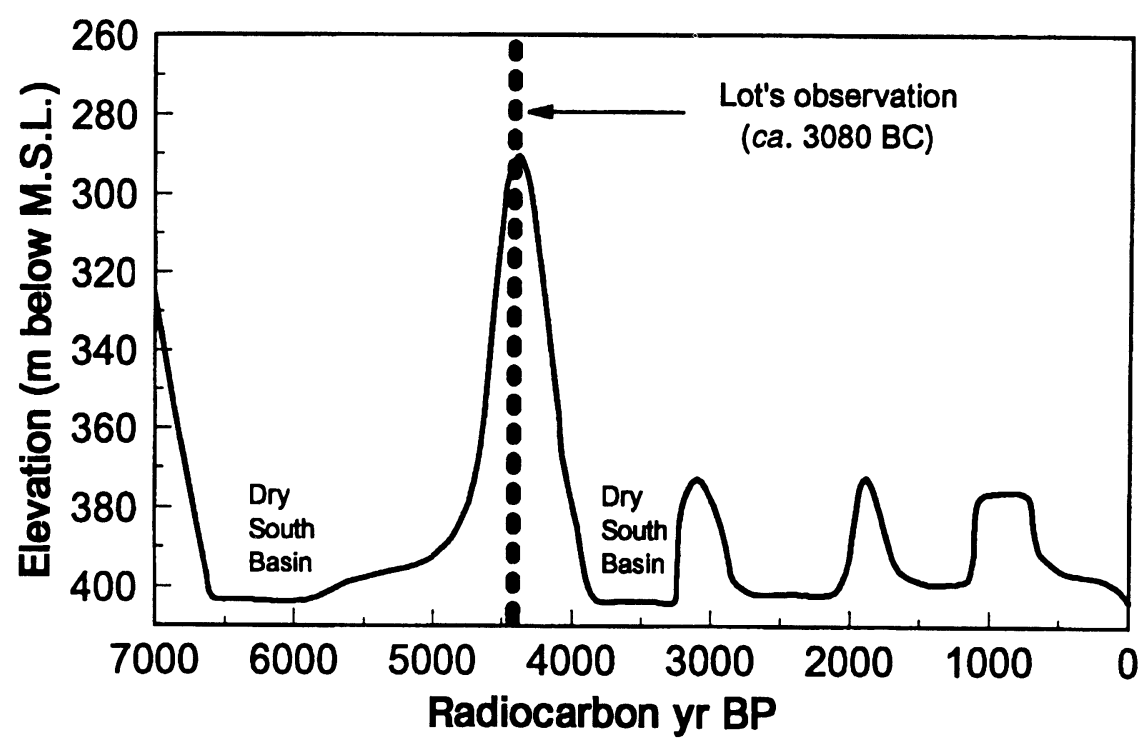

Fig. 2. Temporal coincidence between Lot's biblically recorded observation of the Jordan valley as "well watered everywhere" and a unique moist episode in the Jordan valley indicated by a very high Dead Sea level. (Elevation data after Frumkin et al. 1991)

ous incongruities. It seems reasonable to suggest that the accidental removal of $1000 \mathrm{yr}$ from 1 Kings 6:1 by some ancient scribe is the true source of the many apparent incongruities between the biblical narrative and secular data that fuel the postulate of nonhistoricity at present.

If this is correct, then biblical chronology should begin to assume an important role in the field of historical chronology-building. It can potentially provide absolute dates for specific biblically recorded events back into the early 3 rd and even the 4 th millennium $B C$ within \pm 1 decade. Because many of these events can be correlated with data from archaeology, secular history and past climates, as demonstrated above, it seems possible that biblical chronology could reduce present uncertainties in secular historical chronologies at these early dates by an order of magnitude or more.

\section{ACKNOWLEDGMENTS}

I thank the trustees of the Smith-Walker foundation, and especially Pam McCall, for their support of this research.

\section{REFERENCES}

Aardsma, G. E. 1993 A New Approach to the Chronology of Biblical History from Abraham to Samuel. Santee, California, Institute for Creation Research: $95 \mathrm{p}$.

Archer, G. L., Jr. 1974 A Survey of Old Testament Introduction. Chicago, Moody Press: 507 p.

Avigad, N. 1993 Samaria (City). In Stern, E., ed., The New Encyclopedia of Archaeological Excavations in the Holy Land. Vol. 4. New York, Simon \& Schuster: 1301.

Ben-Tor, A. 1992 The Early Bronze Age. In Ben-Tor, A., ed., The Archaeology of Ancient Israel. New Haven and London, Yale University Press: 8-125.
Bray, J. R. 1971 Solar-climate relationships in the postPleistocene. Science 171: 1242, 1243.

Callaway, J. A. 1985 Was my excavation of Ai worthwhile? Biblical Archaeology Review 11(2): 68, 69. 1993 Ai. In Stern, E., ed., The New Encyclopedia of Archaeological Excavations in the Holy Land. Vol. 1. New York, Simon \& Schuster: 39-45.

Cohen, R. 1983 The mysterious MB I people - does the exodus tradition in the Bible preserve the memory of their entry into Canaan? Biblical Archaeology Review 9(4): 16-29.

1984 Respondents. In Amitai, J., ed., Biblical Ar- 
chaeology Today: Proceedings of the International Congress on Biblical Archaeology, Jerusalem, April, 1984. Jerusalem, Israel Exploration Society: 78-80.

Davis, O. K. 1992 Rapid climatic change in coastal southern California inferred from pollen analysis of San Joaquin marsh. Quaternary Research 37: 89-100.

Dever, W. G. 1980 New vistas on the EB IV ("MB I") horizon in Syria-Palestine. Bulletin of the American Schools of Oriental Research 237: 35-64.

Eddy, J. A. 1976 The Maunder minimum. Science 192(4245): 1189-1202.

Frumkin, A., Magaritz, M., Carmi, I. and Zak, I. 1991 The Holocene climatic record of the salt caves of Mount Sedom, Israel. The Holocene 1(3): 191-200.

Haas, H., Devine, J., Wenke, R., Lehner, M., Wolfli, W., and Bonani, G. 1987 Radiocarbon chronology and the historical calendar in Egypt. In Aurenche, O., Evin, J., and Hours, F., eds., Chronologies in the Near East: Relative Chronologies and Absolute Chronology 16,000-4,000 B.P. Vol. 2. BAR International Series 379. Oxford, England, British Archaeological Reports: 585-606.

Kautz, J. R., III 1986 Moab. In Bromiley, G. W., ed., The International Standard Bible Encyclopedia. Grand Rapids, Eerdmans: 389-396.

Kenyon, K. 1957 Digging up Jericho. New York, Frederick A. Praeger: 272 p.

Kochavi, M. 1993 Leviah enclosure. In Stern, E., ed., The
New Encyclopedia of Archaeological Excavations in the Holy Land. Vol. 3. New York, Simon \& Schuster: 915-916.

Oren, E. D., and Yekutieli, Y. 1990 North Sinai during the MB I Period-Pastoral nomadism and sedentary settlement. Eretz-Israel 21: 6-22.

Redford, D. B. 1992 Egypt, Canaan, and Israel in Ancient Times. Princeton, Princeton University Press: $488 \mathrm{p}$.

Shiloh, Y. 1993 Jerusalem. In Stern, E., ed., The New Encyclopedia of Archaeological Excavations in the Holy Land. Vol. 2. New York, Simon \& Schuster: 709.

Shoemaker, M. 1993 BARlines. Biblical Archaeology Review 19(3): 22.

Sonett, C. P. and Suess, H. E. 1984 Correlation of bristlecone pine ring widths with atmospheric ${ }^{14} \mathrm{C}$ variations: A climate-sun relation. Nature 307: 141-143.

Stuiver, M. and Braziunas, T. F. 1989 Atmospheric ${ }^{14} \mathrm{C}$ and century-scale solar oscillations. Nature 338: 405408.

Stuiver, M. and Reimer, P. 1993 Extended ${ }^{14} \mathrm{C}$ data base and revised CALIB $3.0{ }^{14} \mathrm{C}$ age calibration program. In Stuiver, M., Long, A. and Kra, R. S., Calibration 1993. Radiocarbon 35(1): 215-230.

Wigley, T. M. L. and Kelly, P. M. 1990 Holocene climate change, ${ }^{14} \mathrm{C}$ wiggles and variations in solar irradiance. Philosophical Transactions of the Royal Society of London A 330: 547-560. 